\title{
Religious practices in trauma coping
}

\author{
Khairil Razali \\ The faculty of Tarbiyah IAIN Ar-Raniry Banda Aceh \\ Khairilrazali1976@gmail.com
}

\begin{abstract}
Disasters happen in Indonesia current days bring the country into a very disasterprone country in the Ring of Fire cataclysm. Mega event devastating 2004 tsunami in Aceh Province and Nias have serious consequences for vulnerable groups of parents and children. This paper examines the presence of children in any catastrophic events, especially related to the psychological impact as well as adequate treatments to reduce and eliminate the prolonged psychological trauma. The 2004 tsunami in Aceh and a number of other natural catastrophic disasters have strengthened the effects of traumatic for children in Aceh and elsewhere in Indonesia. A series of earthquakes has built a-sustainable traumatic attitudes within children. This qualitative study learned from children from children centers in Aceh towards their coping strategies and roles of religious practices. In conclusion that it should be a concern to establish social support systems for children to lessen the impact in the future.
\end{abstract}

Bencana yang terjadi di Indonesia dewasa ini menjadikan negara yang sangat rawan bencana dalam Ring of Fire bencana alam. Peristiwa mega dahsyat Tsunami 2004 di Provinsi Aceh dan Nias telah berdampak serius bagi kelompok rentan yaitu orang tua dan anak-anak. Tulisan ini mengkaji tentang keberadaan anakanak dalam setiap peristiwa bencana terutama terkait dengan dampak psikologis bagi mereka serta penanganan yang memadai untuk mengurangi dan menghilangkan trauma psikis yang berkepanjangan. 
Bencana tsunami 2004 dan sejumlah peristiwa bencana alam lainnya telah memperkuat dampak-dampak traumatis bagi anak-anak di Aceh dan tempattempat lain di Indonesia. Serangkaian gempa bumi telah membangun sikap traumatis yang berkesinambungan dalam diri anak-anak. Hal ini perlu menjadi perhatian dari sistim dukungan social sekitar anak-anak untuk mengurangi dampak tersebut di masa yang akan datang.

Keywords: Religious practices; Trauma coping; Aceh; Tsunami

\section{Introduction}

Previous tsunamis show that the effects of their destruction work in complex ways. Before, the 1883 Krakatoa eruption sent tsunami into East Indies coasts, killing an estimated 36,000 . The Lisbon quake caused a rise in tide of 3.6 metres (12 feet), some 5,474 km (3,400 miles) away in Antigua in the Caribbean. ${ }^{1}$ These tsunamis caused impacts physically and mentally to communities.

The impact of natural disasters goes beyond physical effects, often resulting in a range of stresses, both at social and psychological levels. ${ }^{2}$ The effects of the disasters on those directly bereaved were further exacerbated by the nature, scale and public context of the death. ${ }^{3}$ The report stated that infants, young children and elderly to be most at risk from disasters in the Matlab thana of Bangladesh during the crisis years of 1971-2 and 1974-5.

In 2004 tsunami and earthquake, thousands of children suffer from various impacts of the disaster aftermath. Physically and mentally, most children felt into traumatic depression. An article on the Guate-

${ }^{1}$ Anders Wijkman \& Lloyd Timberlake, Prevention Better than Cure, Nottingham, UK: Russel Press, 1984.

${ }^{2}$ Caryl A. Huzzif \& Kevin R. Ronan, "Prediction of Children's Coping Following a Natural Disaster - the Mount Ruapehu Eruptions: A prospective article". The Australasian Journal of Disaster and Trauma Studies, ISSN: 1174-4707, Volume: 1999, 1.

${ }^{3}$ Anne Eyre, "More than PTSD: Proactive Responses Among Disaster Survivors", The Australasian Journal of Disaster and Trauma Studies, Volume: 1998, 2. 
mala earthquake of 1976 revealed that the most vulnerable groups in terms of mortality to children aged five to nine and people aged over 60 years. Indeed, children may become anxious, confused, or frighten.

As a vulnerable group after a disaster children should get more assistance dealing prolonged trauma. A child or an adolescent who experiences a catastrophic event may develop ongoing difficulties known as post traumatic stress disorder (PTSD). The symptom of PTSD may last from several months to many years. A child's risk of developing PTSD is related to the seriousness of the trauma, whether the trauma is repeated, the child's proximity to the trauma, and the relationship to the victims. Children are believed to be exceptionally vulnerable to the effects of trauma due to their underdevelopment cognitive coping mechanisms. ${ }^{4}$

Children exposed to disasters are at risk for a number of mental health related problems. The type and severity depend on the nature and extend of disaster trauma, the influence of family and community, the resilience or vulnerability of the child, and symptom onset and duration. ${ }^{5}$

The issue of children in a disaster is an interesting concern of academics. Much research looks at the issue of children of the disasters aftermath in various countries. Studies investigating the impact of natural disasters on children and adolescents have found negative emotional and behavioral consequences, to varying degrees. ${ }^{6}$ Many children do

${ }^{4}$ Caryl A. Huzzif \& Kevin R. Ronan, "Prediction of Children's Coping Following a Natural Disaster - the Mount Ruapehu Eruptions: A prospective article". The Australasian Journal of Disaster and Trauma Studies, ISSN: 1174-4707, Volume: 1999, 1.

5George W. Doherty, "Cross-Cultural Counseling in Disaster Settings", The Australasian Journal of Disaster and Trauma Studies, ISSN: 1174-4707, Volume: 2000-2.

${ }^{6}$ Caryl A. Huzzif \& Kevin R. Ronan, "Prediction of Children's Coping Following a Natural Disaster - the Mount Ruapehu Eruptions: A prospective article". The Australasian Journal of Disaster and Trauma Studies, ISSN: 1174-4707, Volume: 1999, 1. 
report significant level of emotional distress and frequent occurrence of sub-clinical levels of PTSD. ${ }^{7}$ Moreover, the PTSD symptoms of vigilance, visual hallucinations, and visual avoidance, if chronic, may evolve into long standing cognitive, personality, and interpersonal deficits. ${ }^{8} \mathrm{~A}$ natural disaster can be characterized by the fact that individuals fear the loss of their own life, or witness the death of others, and are frequently unable to act in any way to prevent harm. ${ }^{9}$

This article looks at the issue of the effects of the disaster toward children that causes various impacts mentally or physically. The possibility of a prolonged traumatic experience of children relates to the coping behavior toward trauma healing. Therefore, this article tries to reflect of how children in disaster regarding the impacts towards them.

There have been researches into the effects of major traumatic events is immense importance to public administration, health policy and clinical practice. ${ }^{10}$ Therefore, this article looks, learn, and gives an overview the phenomena arising in disaster aftermath in Aceh related to the trauma healing of children in disaster.

\section{Research methods}

This study used random sampling. This research only had a short term to compile with the fieldwork data collection. The number of chil-

\footnotetext{
${ }^{7}$ Caryl A. Huzzif \& Kevin R. Ronan, "Prediction of Children's Coping Following a Natural Disaster - the Mount Ruapehu Eruptions: A prospective article". The Australasian Journal of Disaster and Trauma Studies, ISSN: 1174-4707, Volume: 1999, 1

${ }^{8}$ James W. Ellor, F. Ellen Netting, and Jane M. Thibault, Understanding Religious and Spiritual Aspects of Human Service Practice, Columbia, South Carolina: University of South Carolina Press, 1999.

'Sally Anna Kydd, A Case Article of Program Planning and Evaluation in Assisting Montserratian Evacuees and British Government Officials in Natural Disaster Planning, New Jersey, Dissertation, 1999.

${ }^{10} \mathrm{John}$ Raftery, "Doing Better than Media: Ethical Issues in Trauma Research", The Australasian Journal of Disaster and Trauma Studies, 1997.
} 
dren affected in the tsunami, or the population from which this study samples, was a large number. Random sampling may help to derive a representative sample from this large population so that results from this work can inform work or research with other parts of the larger population of children.

The selection of random sampling related to the time and financial consideration. The availability of resource for the data collection was not a significant issue but due to the limitation of time, the writer used the random sampling in approaching respondents.

In this study, the researcher prepared 400 students to take part. This representation might be delegate the majority number of children in Aceh who affected by the tsunami and earthquake. This number was hoped the ideal number in researching an issue in research field. By using the random sampling method in schools and children centers, the researcher only distributes the questionnaires by facilitated of teachers and staff.

This method is believed helpful in order to get better response from children toward the questionnaire in giving their information by the questions asked. Children from two public schools and two children centers may contribute and reflect the perspective of other children suffered from devastated tsunami at the end of 2004. As the result of the questionnaires distribution for the data collection, the researcher could get the response from 53 respondents.

\section{The impacts of disasters}

Natural disasters have short and long term impacts. Dynes divides the concept of natural disaster into two aspects, traumatic event itself, such as tornado, hurricane, fire, or volcanic eruption, emphasizing the destructive power of the event, and the human or community re- 
sponse to the event, namely terror, loss and social eruption. ${ }^{11}$ In a cataclysmic disaster, one large-scale event causes most of the damage and destruction. ${ }^{12}$

Tyhurst outlined three stages that describe behaviors that occur in response to a disaster. The first is called the impact phase and occur when disaster strikes, and continues until the immediate stress of the event no longer exerts a force. ${ }^{13}$ In any kind of disaster whether natural or man-made disaster, it is absolutely resulted the impacts to entire communities. The more serious the disaster is, the more impacts would be. Although it is only cataclysmic or long-term disaster, the impacts always bring the difficult consequences to human beings.

Children may appear more resilient in their response and recovery from disasters. ${ }^{14}$ The dramatic destruction of the tsunami in 2004 had major impacts towards elderly and children. As a result, children reacts to trauma may appear immediately after the traumatic event or days and even weeks later.

Following a disaster, children may suffer from PTSD which is physically damaged that can result from experiencing, witnessing, or participating in an overwhelming traumatic (frightening) event. Therefore, professional advice or treatment for children affected by a disaster especially those who have witnessed destruction, injury or death can help prevent or minimize PTSD. Traumas typically occur suddenly, often leaving children little or no time to prepare physically or emotionally.

${ }^{11}$ Russel R. Dynes, Organized Behavior in Disaster, Lexington, Massachussets: D.C. Heath and Company, 1970.

${ }^{12}$ Frederick C. Cuny. Disaster and Development, New York: Oxford University Press ,1983.

${ }^{13}$ Sally Anna Kydd, A Case Article of Program Planning and Evaluation in Assisting Montserratian Evacuees and British Government Officials in Natural Disaster Planning, New Jersey, Dissertation, 1999.

${ }^{14}$ George W. Doherty, "Cross-Cultural Counseling in Disaster Settings", The Australasian Journal of Disaster and Trauma Studies, ISSN: 1174-4707, Volume: 2000-2. 
Traumas are unpredictable and outside what are to be expected in children's lives. ${ }^{15}$

Children who face the simultaneous and destructive events become seriously vulnerable to suffer from the trauma. An event is 'traumatic' if it overwhelms the organism, dramatically and negatively disrupting homeostasis. ${ }^{16}$

Children exposed to disasters are at risk for a number of mental health related problems. The type and severity depend on the nature and extend of disaster trauma, influence of family and community, resilience or vulnerability of the child, and the symptom onset and duration. ${ }^{17}$

Becoming stressful was the phase of the disasters aftermath for most children and in doing so, individual adaptive stress response during a trauma or stress is varied. ${ }^{18}$ In this fact, parents can be instrumental in their children recovery. It is believed that there are also different ways in treating children from continuing trauma, the roles of family, and environments are considered important. Therefore, the attachment to certain figure plays a main role in trauma recovery of children. The attachment behavior is designed to get children into a close, protective relationship with their attachment figures whenever they experience anxiety. ${ }^{19}$

\footnotetext{
${ }^{15}$ Philip J. Lazarus, Trauma and Children: A Parent Handout for Helping Children Heal, Florida: International University, 2006.

${ }^{16}$ Bruce D. Perry, "Stress, Trauma and Post-traumatic Stress Disorder in Children: An Introduction", The Child Trauma Academy, 2000.

${ }^{17}$ George W. Doherty, "Cross-Cultural Counseling in Disaster Settings", The Australasian Journal of Disaster and Trauma Studies, ISSN: 1174-4707, Volume: 2000-2.

${ }^{18}$ Bruce D. Perry, "Stress, Trauma and Post-traumatic Stress Disorder in Children: An Introduction", The Child Trauma Academy, 2000.

${ }^{19}$ David Howe, Marian Brandon, Diana Hinings, \& Gillian Schofield, Attachment Theory, Child Maltreatment and Family Support: A Practiced and Assessment Model. New Jersey: Lawrence Erlbaum Associates, 1999.
} 
The children experience a variety of reactions and feelings in response to a disaster and need special attention to meet their need. Therefore, children may suffer from various impacts in disasters not only traumatic aspects but also their childhood moment. It is important constantly to bear in mind that trauma is not simply a collection of symptoms, as it is often portrayed - in fact symptoms may not follow all traumatic situations.

Although the duration of the impacts of disasters of children and other groups much depend on the treatments, counseling, and their coping strategies. It is believed that there are no quick fixed phases to deal with the PTSD of the disasters aftermath. However, recovery is inevitability a lengthy and culturally-bounded process.

\section{Trauma of disaster}

\section{Mental depression}

Disaster always results complex problems to communities and environment. They could take longer period to deal with the aftermath consequences. Disasters involve deaths, loss of properties and the most important is psychological trauma. The meaning of trauma is various depend on the context and the circumstance we use. Giller writes that trauma in everyday language to mean a highly stressful event. ${ }^{20}$

Psychological trauma is the unique individual experience of an event or enduring conditions, in which: The individual's ability to integrate his/ her emotional experience is overwhelmed, or; The individual experiences (subjective) a threat to life, bodily integrity, or sanity. ${ }^{21}$

The level of individual or a child reacts to a traumatic event would influence the occurring of acute stress that can lead to trauma. Psy-

${ }^{20}$ Esther Giller, What is Psychological Trauma?. Sidran Foundation, 2000.

${ }^{21}$ Esther Giller, What is Psychological Trauma?. Sidran Foundation, 2000. 
chological trauma is a situation where individuals or in this case children receive or experience a certain tragically moment. The earthquake and Tsunami in 2004 in Aceh Province was increased the children into the prolonged psychological trauma due to their loss, and experiences.

Giller adds that the definition of trauma is fairly broad. The more you believe you are endangered, the more traumatized you will be.22 Children reactions will depend much on their age which is vary. So, It would be different reactions from age 2 years to 18 years. However, the psychological trauma depends on the experience of children faced. It is believed that children would face a tendency to mental depression. Children in this developmental stage may differ greatly in their interpretations and reactions to disasters depending on whether they have developed abstract reasoning abilities. ${ }^{23}$

Children are believed to be exceptionally vulnerable to the effects of trauma due to their underdeveloped cognitive coping mechanisms. ${ }^{24}$ Moreover, Atkins has shown that increased age is positively related to more active modes of coping in the face of traumatic stressors. ${ }^{25}$ Indeed, children have less control over environment contingencies found helpful for reducing stress compared to adults. ${ }^{26}$

Stress that leads to trauma mostly results the mental acute problems for individuals and children is a vulnerable group mainly of the

\footnotetext{
22Esther Giller, What is Psychological Trauma?. Sidran Foundation, 2000.

${ }^{23}$ Joseph F. Hagan, "Psychosocial Implications of Disaster or Terrorism on Children: A Guide for the Pediatrician", Pediatrics, Vol. 116 No. 3 September 2005: 787-795.

${ }^{24}$ Caryl A. Huzzif \& Kevin R. Ronan, "Prediction of Children's Coping Following a Natural Disaster - the Mount Ruapehu Eruptions: A prospective article". The Australasian Journal of Disaster and Trauma Studies, ISSN: 1174-4707, Volume: 1999, 1.

${ }^{25}$ Caryl A. Huzzif \& Kevin R. Ronan, "Prediction of Children's Coping Following a Natural Disaster - the Mount Ruapehu Eruptions: A prospective article". The Australasian Journal of Disaster and Trauma Studies, ISSN: 1174-4707, Volume: 1999, 1.

${ }^{26}$ Caryl A. Huzzif \& Kevin R. Ronan, "Prediction of Children's Coping Following a Natural Disaster - the Mount Ruapehu Eruptions: A prospective article". The Australasian Journal of Disaster and Trauma Studies, ISSN: 1174-4707, Volume: 1999, 1.
} 
disasters aftermath. Children may be more affected by a traumatic event for a longer period of time than others. Individuals who have experienced trauma are at heightened risk for developing other psychiatric disorders, including depression, substance abuse, panic disorder, obsessive-compulsive disorder, sexual dysfunction, and eating disorders.

Dramatic, rapid, unpredictable, or threatening changes in the environment, however, will activate 'stress'-response systems. ${ }^{27}$ Therefore, coping becomes critical issue in competency/vulnerability models of child and adolescent psychopathology. ${ }^{28}$ Disasters that result in a loss of lifestyle or loved ones can result in somatization, withdrawal, apathy, and depression. ${ }^{29}$ In doing so, it is important to provide children with better treatment in order to avoid a prolonged mental depression in particular.

\section{Traumatic Memories}

Trauma can change the way children view their world. Assumption about safety and security are now challenged. ${ }^{30}$ Children with acute PTSD would view the carefully and differently from before. In PTSD, a psychiatric diagnosis common among people who have survived horrific events, the defining diagnostic features are memory distortions.

The situation of fears, worries, and nightmares are common following a trauma. ${ }^{31}$ Children suffered from a tragic disaster such as in Aceh

\footnotetext{
${ }^{27}$ Bruce D. Perry, "Stress, Trauma and Post-traumatic Stress Disorder in Children: An Introduction", The Child Trauma Academy, 2000.

${ }^{28}$ Steven L. Berman, Wendy K. Silverman \& William M. Kurtines, "Children's and Adolescent' Exposure to Community Violence, Post-Traumatic Stress Reactions, and Treatment Implications", The Australasian Journal of Disaster and Trauma Studies, ISSN: 1174-4707, Volume: 2000-1.

${ }^{29}$ Joseph F. Hagan, "Psychosocial Implications of Disaster or Terrorism on Children: A Guide for the Pediatrician", Pediatrics, Vol. 116 No. 3 September 2005: 787-795.

${ }^{30}$ Philip J. Lazarus, Trauma and Children: A Parent Handout for Helping Children Heal, Florida: International University, 2006.

${ }^{31}$ Philip J. Lazarus, Trauma and Children: A Parent Handout for Helping Children Heal, Florida: International University, 2006.
} 
in 2004 taken into acute PTSD. The natural disaster that they never experienced before has brought certain memory toward them. The development of PTSD which is the psychological damage that can result from experiencing, witnessing, or participating in an overwhelmingly traumatic (frightening) event. Symptoms of avoidance consist of attempts to avoid reminders of event, including persons, places, or even thoughts associated with the incident. ${ }^{32}$

Children with lower self-ability to cope with the disasters and other natural phenomena would lead them into a continuation of traumatic experience. PTSD rarely appears during the trauma itself. The disorder often surfaces several months or even years later. So there would be a common feature of the disaster aftermath by various resistances to return to previous living place of many communities. It is also natural for children to first experience some sort of denial. ${ }^{33}$ Some people say they are "haunted" by memories of traumatic experiences which intrude on and disrupt their daily lives.

Indeed, traumatic events can lead children and other groups suffer from psychological trauma for a certain period of time. The occurrence of traumatic memories is not only result from disasters but also from conflicts or social disorders as well abuses. Sexual abuses or physical abuses were also contributed to the mentally trauma.

\section{Trauma healing}

It has now been revealed that the community as an institution in itself is emerging as the most powerful in the entire mechanism of disaster

\footnotetext{
${ }^{32}$ Rachel Yehuda "Post-Traumatic Stress Disorder", The New England Journal of Medicine, Volume 346:108-114, 2002.

${ }^{33}$ Philip J. Lazarus, Trauma and Children: A Parent Handout for Helping Children Heal, Florida: International University, 2006.
} 
administration. ${ }^{34}$ Any difficult situation as a result of a natural event brings various consequences and impacts. It could be short term or long term. In other words, people would fall into critical situation.

Disasters may strike the community with or without any signals. Disaster is thought of as mass destruction of property and extensive injury and death to person. ${ }^{35}$ Disasters may result psychological illness in a prolonged period mainly suffered by children.

There are three important stages after a disaster strikes a community which are emergency, rehabilitation and reconstruction stages. These three stages as the result of disasters need various kinds of supports to rebuild the damaged community. Emergency stage results many serious disruption and difficulties toward victims. Ultimately the emergence of new social relationship is realized. ${ }^{36}$

In any phase of disaster, it is needed various reactions and responses from all parties to help the affected people and vulnerable groups trapped in problems. The existence humanitarian groups and governments should be in front line in order to provide immediate assistance for affected people in any kinds of disasters. The seriousness of mental impact of disasters toward children may lead to various forms of reactions. It could be anxiety, fears, changes in behavior, repetitive thoughts and comments about death or dying, etc. ${ }^{37}$ In anticipating the acute stress and depression on children, all elements should give greater support in assisting children cope with traumatic experience.

\footnotetext{
${ }^{34}$ Sachidra Narayan, Sachindra. Anthropology of Disaster Management (Anthropology, Industry, Management, Sociology), India: Gyan Publishing House, 2000.

${ }^{35}$ William H. Nosow and Sigmund Freud, Community in Disaster. USA: Harper \& Brothers, 1958.

${ }^{36}$ William H. Nosow and Sigmund Freud, Community in Disaster. USA: Harper \& Brothers, 1958.

${ }^{37}$ Robert H. Gurwitch et al. Reactions and Guidelines for children Following Trauma/Disaster, Oklahoma: Department of Pediatric, University of Oklahoma Health Science Center, 2005.
} 
The threat of trauma occurrence may show the importance of full social support for children in particular. They would perform different response toward the impacts of disasters based on their age. Children certainly look significantly on adults in their lives for guidance on how to manage their reactions after immediate threat is over. ${ }^{38}$ The fact that it is important to help survivors recognize the normalcy of most stress reactions to disaster.

Gurwith et al.offer several steps in treating school children after trauma as follows: ${ }^{39}$ Reinforce ideas of safety and security; Listen to and tolerate your students retelling events; Provide reassurance to the students that feeling will get smaller and easier to handle over time; Protect students from re-exposure to frightening situations and reminders of events in front of students.

The tsunami and earthquake in 2004 in Aceh Province was considered the most tragic natural disaster ever in term of the victims. The impacts of these phenomena are sudden with little or no warning making it just impossible to predict or to make preparations against. ${ }^{40}$

The government as a stakeholder has shown up all abilities in assisting major affected group like children, the children of the tsunami need particular care in recovering from extreme levels of uncertainty, abandonment, confusion, insecurity as well as direct exposure to high level of loss, death, human suffering, injury, and mistreatment. ${ }^{41}$

\footnotetext{
${ }^{38}$ Philip J. Lazarus, Trauma and Children: A Parent Handout for Helping Children Heal, Florida: International University, 2006.

${ }^{39}$ Robert $\mathrm{H}$. Gurwitch et al. Reactions and Guidelines for children Following Trauma/Disaster, Oklahoma: Department of Pediatric, University of Oklahoma Health Science Center, 2005.

${ }^{40}$ Sachidra Narayan, Sachindra. Anthropology of Disaster Management (Anthropology, Industry, Management, Sociology), India: Gyan Publishing House, 2000.

${ }^{41}$ Amanda Allan "Psychosocial Support for Children Affected by the Tsunami", Health and Psycho-social Issues, Melbourne: Melbourne University Press, 2005.
} 
Furthermore, at any disasters always attract concerns of many parties and agents to get involved in emergency situation, relief efforts, rehabilitation and reconstruction. Disasters need many sorts of activities to help people affected dealing with recovering effort. Recovery from the event involves confronting human vulnerability in away that promotes the development of resilience. ${ }^{42}$

Traumatic and disrupting events can have adverse effects even on children who are too young to verbalize their distress. Parents and caregivers can expect children to respond to disaster in distinct stages. ${ }^{43}$

The availability of social support assists children from prolonged exposure of traumatic events. The family should fully provide the support in order to put the children from deeper upset by lacking of support. This article explored 53 children to learn the impacts of previous disasters in Aceh in particular. There was nearly equal number of male $(54.7 \%)$ and female $(45.3 \%)$ respondents.

Of the respondents above that one of the consequences that most children in disasters lost social supports. This condition was one main contribution of increasing Post-traumatic Stress Disorder for children of the disaster aftermath. It was believed that the loss of properties influenced mental stability of people affected in disasters. On the other hand, the healing process of traumatic experience would be difficult on children in particular. In addition, children have to flee to safer place from the disaster hit areas and many of them should become internally displaced people. In tsunami 2004 in Aceh of this study, 30 children $(58.8 \%)$ had lived in temporary settlements while 20 children $(39.2 \%)$ mentioned that they did not live in shelters.

${ }^{42}$ Rachel Yehuda, "Post-Traumatic Stress Disorder", The New England Journal of Medicine, Volume 346:108-114, 2002.

${ }^{43}$ Joseph F. Hagan, "Psychosocial Implications of Disaster or Terrorism on Children: A Guide for the Pediatrician", Pediatrics, Vol. 116 No. 3 September 2005: 787-795. 
Another significant issue of post disaster was separated children. Thousands of children lost their parents and family members in which the moment could increase the symptom of trauma. In any disasters no exception of 2004 tsunami in Aceh, many children were neglected and ignored or lost direction to whom they should attach.

\section{Religious roles in trauma recovery}

\section{Religious values}

Clinicians and researchers have studied the questions of whether religion is more likely to have positive or negative effects on mental health. The results have been inconsistent. ${ }^{44}$ Religion is simply considered an important aspect in mental health recovery issue due to the belief of the person in God. Research has also linked religious beliefs and involvement to health beliefs, attitudes, and behaviors, and improved well-being. ${ }^{45}$ Payne et al. concluded that while religion is correlated with self-esteem, well-being, personal adjustment, and suicide, there is "little evidence supporting religious influence in the prevention of serious clinical diagnosis like bipolar disorders, major depression, schizophrenia, obsessions, and panic disorders". ${ }^{46}$

Children who much pure on their belief and their strong faith believed have perception of religion role in the trauma recovery. Their belief in God plays important influence toward their acceptance of difficulties. There would have a tendency to believe that problems come

\footnotetext{
${ }^{44}$ James W. Ellor, F. Ellen Netting, and Jane M. Thibault, Understanding Religious and Spiritual Aspects of Human Service Practice, Columbia, South Carolina: University of South Carolina Press, 1999.

${ }^{45}$ Alexandra Boeving, Adjustment to Childhood Chronic Illness: Prediction of Psychological Adjustment with an Investigation into Spiritual Coping, Virginia: Master Thesis, 2000.

${ }^{46}$ Ram A. Cnaan, Robert J, Wineburg, \& Stephani C. Boddie, The Newer Deal: Social Work and Religion Partnership, New York: Columbia University Press, 1999.
} 
with the solutions. Through the religious beliefs of life after death, prayer, and $\sin ^{47}$, here religious values can intervene the understanding of children on facing the psychological trauma. Spilka and his colleagues found that children from religious families who had cancer and their families exhibit better ability to cope with death than did nonreligious children and their families. ${ }^{48}$

Cancer patients who endorse strong religious faith exhibit higher scores on hope and coping scales that those patients who do not indicate strong faith. ${ }^{49}$ In social work, religious values are only one of several sources of influence on social work practice. ${ }^{50}$

Spilka, Zwartjes, and Zwartjes conducted a study evaluating the important of religion in coping with childhood cancer, and found that religion appeared to facilitate connectiveness for the child with his/her family members through the "talking out" of illness-related feeling. ${ }^{51}$ In another words, religion can facilitate children reduce the problems by believing in God. Many religions assert that God judges humanity, both individually and as a group. ${ }^{52}$ Indeed it could encourage people in facing any disasters due to the impacts.

Disasters for children are difficulty for their growth mentally or physically. Extremely they would suffer from PTSD in various forms. Chil-

\footnotetext{
${ }^{47}$ James W. Ellor, F. Ellen Netting, and Jane M. Thibault, Understanding Religious and Spiritual Aspects of Human Service Practice, Columbia, South Carolina: University of South Carolina Press, 1999.

${ }^{48}$ Ram A. Cnaan, Robert J, Wineburg, \& Stephani C. Boddie, The Newer Deal: Social Work and Religion Partnership, New York: Columbia University Press, 1999.

${ }^{49}$ Alexandra Boeving, Adjustment to Childhood Chronic Illness: Prediction of Psychological Adjustment with an Investigation into Spiritual Coping, Virginia: Master Thesis, 2000.

${ }^{50}$ Frank M. Loewenberg, Religion and Social Work Practice in Contemporary American society, New York: Columbia University Press, 1988.

${ }^{51}$ Alexandra Boeving, Adjustment to Childhood Chronic Illness: Prediction of Psychological Adjustment with an Investigation into Spiritual Coping, Virginia: Master Thesis, 2000.

${ }^{52}$ James W. Ellor, F. Ellen Netting, and Jane M. Thibault, Understanding Religious and Spiritual Aspects of Human Service Practice, Columbia, South Carolina: University of South Carolina Press, 1999.
} 
dren maybe think that religion is a central part of their life in which could help them release from psychosocial illness. In social work practice the significance of religion goes far beyond the practice of those who are formally identified as religious. ${ }^{53}$

Religious values become the crucial underpinnings for coping with traumatic memory, anxiety, and stress. The stronger religious values they have, the easier they heal with. God offers a source of support and assistance and God is the ultimate source of explanation ..$^{54}$ Therefore, religious values play major influences dealing with mental health of children and other vulnerable groups in a disaster.

\section{Religious practices}

Religious recovery is believed to bring great influence on mental stability. The acute PTSD as a consequence of disasters could be released along the treatment process. The nature and intensity of post-disaster stress reactions may be affected by the demands placed upon people by their respective religion. ${ }^{55}$

All religions entail behaviors that are intended to be congruent with the basic tenets of the faith. Most of the world traditions have specific rituals in which members participate. ${ }^{56}$ Jacobs concludes that religious ceremony and ritual functions mitigate anxiety and deal effectively with

\footnotetext{
${ }^{53}$ Frank M. Loewenberg, Religion and Social Work Practice in Contemporary American society, New York: Columbia University Press, 1988.

${ }^{54}$ James W. Ellor, F. Ellen Netting, and Jane M. Thibault, Understanding Religious and Spiritual Aspects of Human Service Practice, Columbia, South Carolina: University of South Carolina Press, 1999.

${ }^{55}$ Matt Gilard and Douglas Paton, "Disaster Stress Following a Hurricane: The role of religious differences in the Fujian Islands", The Australasian Journal of Disaster and Trauma Studies, ISSN: 1174-4707, Volume: 1999-2.

${ }^{56}$ James W. Ellor, F. Ellen Netting, and Jane M. Thibault, Understanding Religious and Spiritual Aspects of Human Service Practice, Columbia, South Carolina: University of South Carolina Press, 1999.
} 
other problematic emotional states. ${ }^{57}$ Indeed, religion can play important role in the care for and adaptation of mentally ill people in the community. ${ }^{58}$

There are many studies on the significant role of religion in various fields of studies. There were found that religion gave major influence toward the recovery and recovery process toward individuals. Several studies (e.g., Dewey, 1988; Walls \& Zarit, 1991; Eng et al, 1985; Pargament, 1986) have shown religion to be an important determinant of traumatic reactivity. ${ }^{59}$ One study suggesting an association between religion and mental health was performed by McDonald and Luckett in 1983. They found that clients who reported they had no religion were more likely to be substance abuser and/or paranoid schizophrenics, hostile and aggressive, and more likely to be diagnosed with a neurosis. ${ }^{60}$

For many people religious beliefs and practices serve positive functions in maintaining their mental health. ${ }^{61}$ Hannay in 1980 and Zuckerman, Kasl, and Ostfeld in 1984 also reported that that regular church attendance and strong religious beliefs are associated with improved physical health and reduce mortality. ${ }^{62}$

Prayer and attendance to the religious activities are two basic practices that could assist the community in reducing the mental problems

\footnotetext{
${ }^{57}$ George W. Doherty, "Cross-Cultural Counseling in Disaster Settings", The Australasian Journal of Disaster and Trauma Studies, ISSN: 1174-4707, Volume: 2000-2.

${ }^{58}$ Ram A. Cnaan, Robert J, Wineburg, \& Stephani C. Boddie, The Newer Deal: Social Work and Religion Partnership, New York: Columbia University Press, 1999.

${ }^{59}$ Matt Gilard and Douglas Paton, "Disaster Stress Following a Hurricane: The role of religious differences in the Fujian Islands", The Australasian Journal of Disaster and Trauma Studies, ISSN: 1174-4707, Volume: 1999-2.

${ }^{60}$ Ram A. Cnaan, Robert J, Wineburg, \& Stephani C. Boddie, The Newer Deal: Social Work and Religion Partnership, New York: Columbia University Press, 1999.

${ }^{61}$ Frank M. Loewenberg, Religion and Social Work Practice in Contemporary American society, New York: Columbia University Press, 1988.

${ }^{62}$ Ram A. Cnaan, Robert J, Wineburg, \& Stephani C. Boddie, The Newer Deal: Social Work and Religion Partnership, New York: Columbia University Press, 1999.
} 
mainly in disasters. Reeves $(1989,1990)$ suggests that ritual can be used to assist individuals to move from maladaptive to an adaptive style of grieving. ${ }^{63}$

Polls hoping to gauge the importance of religion and spirituality in American life tend to define religion in relation to 1) institutional factors such as membership, synagogue, or church attendance, religious preference, and denominational affiliation; 2) belief in God, miracles, life after death, the Bible; and 30 practices such as prayer and Bible reading. ${ }^{64}$

The statistical data shows different facts between Muslim and Christian children. Muslim children of mean 33.34 mean that they might be better in coping compared to Christian children. This might be caused by some reasons such social support of personal coping abilities.

As a result that lower coping ability in trauma, the majority of Christian children suffered from higher psychological trauma compared to Muslim group. By the 46.90, Christian children might be caused from limited of support post disaster.

Religious practice shows that Muslim children take higher position which meant that Muslim children relied much on religion in assisting the traumatic healing and psychological pressure. Therefore, the statistical data shows the differences between Muslim and Christian children in coping, psychological trauma and religious practice.

In a study focused on the well being of women examined the effects of religion and spirituality of fifty homeless women in Los Angeles, prayer was reported as an effective strategy by almost half of the

\footnotetext{
${ }^{63 G e o r g e ~ W . ~ D o h e r t y, ~ " C r o s s-C u l t u r a l ~ C o u n s e l i n g ~ i n ~ D i s a s t e r ~ S e t t i n g s ", ~ T h e ~ A u s t r a l a s i a n ~}$ Journal of Disaster and Trauma Studies, ISSN: 1174-4707, Volume: 2000-2.

${ }^{64}$ Linda L. Barnes, Gregory A. Plotnikoff, Kenneth Fox \& Sara Pendleton, "Subject Revies: Spirituality and Foster Care: Spirituality, Religion, and Pediatrics: Intersecting Worlds of Healing", Pediatrics, Vol. 106 No. 4, 2000.
} 
women (48\%), and a small percentage (8\%) said that referral for spiritual or religious consultation would have been helpful. ${ }^{65}$ Prayer fills a variety of different functions in various religions. Some religious social workers have utilized prayers as an intervention technique because they believe in prayer's efficacy. ${ }^{66}$

This study looked at the correlation between religious practice and psychological trauma of affected children and the facts shown of 53 children respondents said that religion did not give significant correlation toward the trauma psychological of them. In addition, children did not state that religious practice play roles significantly. This might be describe the feature of children tend to rely on modern trauma healing rather than religious practice.

Religious practice as a component in coping might be not considered as urgent as possible by most children; as a result, they did not rely significantly on religion. Indeed, from this statistical data shows that between religious practice and psychological trauma did not have significant correlation.

\section{Conclusion}

This research found that the coping behavior played a role in children's trauma healing in contrast religious did not play significant role after the tsunami in Banda Aceh, but the integration between coping behavior and the religion through its practices and values has given influences in how children cope with the traumatic life experience they faced during the tsunami. Ritual was one major religious way in healing the trauma that has given major influence for children. Ritual attendances in any

${ }^{65}$ Ram A. Cnaan, Robert J, Wineburg, \& Stephani C. Boddie, The Newer Deal: Social Work and Religion Partnership, New York: Columbia University Press, 1999.

${ }^{66}$ Frank M. Loewenberg, Religion and Social Work Practice in Contemporary American society, New York: Columbia University Press, 1988. 
religion are believed to help children getting their peaceful mind in their efforts to cope with the trauma.

Between Muslim and Christian students, there were the differences in that Christian children relied more on religion. This circumstance has shown children understanding for religion and its values in trauma healing. Impacts of the disasters in many aspects including mentally were believed could result certain level of traumatic memories on children. Children who loss parents and houses for instance would be remain in trauma for a longer period. But, the availability of social support continually has taken important.

Furthermore, the seriousness of mental impact of disasters toward children may lead to various forms of reactions. It could be anxiety, fears, changes in behavior, repetitive thoughts and comments about death or dying, etc. ${ }^{67}$ Therefore, the interventions toward various behavior related with the PTSD have been given major attention in helping children. Anxiety or afraid of something would be the indication of their mental stability. Many children resist returning on their previous places or homes due to their experiences in disasters. Children may be wanted to relocate to safer location in order to reducing the traumatic memories suffered from the tsunami.

\section{Bibliography}

Allan, Amanda. Psychosocial Support for Children Affected by the Tsunami. Health and Psycho-social Issues. Melbourne University. Http:/ /www.developmentgateway.com.au/jahia/Jahia/pid2188, 2005, retrieved on March 13, 2006.

${ }^{67}$ Robert H. Gurwitch et al. Reactions and Guidelines for children Following Trauma/Disaster, Oklahoma: Department of Pediatric, University of Oklahoma Health Science Center, 2005. 
Barnes, Linda L., Plotnikoff, Gregory A., Fox, Kenneth., \& Pendleton, Sara, "Subject Revies: Spirituality and Foster Care: Spirituality, Religion, and Pediatrics: Intersecting Worlds of Healing", Pediatrics, Vol. 106, No. 4 (October 2000).

Berman, Steven L., Silverman, Wendy K., \& Kurtines, William M., "Children's and Adolescent' Exposure to Community Violence, PostTraumatic Stress Reactions, and Treatment Implications", The Australasian Journal of Disaster and Trauma Studies, Volume 20001.

Boeving, C. Alexandra, "Adjustment to Childhood Chronic Illness: Prediction of Psychological Adjustment with an Investigation into Spiritual Coping", Master Thesis. Virginia, 2000.

Cnaan, Ram A., Wineburg, Robert J., \& Boddie, Stephani C. The Newer Deal; Social Work and Religion Partnership. New York: Columbia University Press, 1999.

Cuny, Frederick C. Disaster and Development. New York: Oxford University Press, 1983.

Curson, Peter. Population and Disaster. Great Britain: Butler \& Tanner Ltd., 1989.

Doherty, George W., "Cross-Cultural Counseling in Disaster Settings", The Australasian Journal of Disaster and Trauma Studies, Volume: 2000-2.

Dynes, Russell R. Organized Behavior in Disaster. Lexington: D.C. Heath and Company. Massachusetts, 1970.

Ellor, James W, Netting, F.Ellen, and Thibault, Jane M. Understanding Religious and Spiritual Aspects of Human Service Practice. Columbia, South Carolina: University of South Carolina Press, 1999. 
Eyre, Anne, "More than PTSD: Proactive Responses Among Disaster Survivors", The Australasian Journal of Disaster and Trauma Studies, Volume 1998-2.

Form, William H., Nosow, Sigmund. Community in Disaster. The United States of America: Harper \& Brothers, 1958.

Gilard, Matt and Paton, Douglas, "Disaster Stress Following a Hurricane: The role of religious differences in the Fujian Islands", The Australasian Journal of Disaster and Trauma Studies, Volume: 19992.

Giller, Esther. What is Psychological Trauma?. Sidran Foundation. http:/ /www.sidran.org/trauma.html, 2000, retrieved on April 25, 2006.

Gurwitch, Robert $\mathrm{H}_{\text {., }}$ et al. Reactions and Guidelines for children Following Trauma/Disaster. Department of Pediatric. America: University of Oklahoma Health Science Center, 2006.

Hagan, Joseph F., et al. "Psychosocial Implications of Disaster or Terrorism on Children: A Guide for the Pediatrician", Pediatrics, Vol. 116, No. 3 (September 2005): 787-795. Http://pediatrics. aappublications.org/cgi/content/full/116/3/787. Retrieved on April 25, 2006.

Howe, David., Brandon, Marian., Hinings, Diana., Schofield, Gillian. Attachment Theory, Child Maltreatment and Family Support: A Practiced and Assessment Model. New Jersey: Lawrence Erlbaum Associates, 1999.

Huzzif, Caryl A and Ronan, Kevin R., "Prediction of Children's Coping Following a Natural Disaster - the Mount Ruapehu Eruptions: A prospective article", The Australasian Journal of Disaster and Trauma Studies, Volume: 1999-1. 
Kydd, Sally Anna, "A Case Article of Program Planning and Evaluation in Assisting Montserratian Evacuees and British Government Officials in Natural Disaster Planning", Dissertation. New Brunswick, New Jersey, 1999.

Lazarus, Philip J. Trauma and Children: A Parent Handout for Helping Children Heal. Florida International University. http:// www.nasponline.org/NEAT/ptsd.html, retrieved on June 27, 2006. Loewenberg, Frank M. Religion and Social Work Practice in Contemporary American Society. New York: Columbia University Press, 1988. Narayan, Sachindra. Anthropology of Disaster Management (Anthropology, Industry, Management, Sociology). India: Gyan Publishing House, 2000.

Perry, Bruce D. Stress, Trauma and Post-traumatic Stress Disorder in Children: An Introduction. The ChildTrauma Academy, 2002, www.childtrauma.org/CTAMATERIALS/PTSDfn_03_v2.pdf, retrieved on June 27, 2006.

Raftery, John. Doing Better than Media: Ethical Issues in Trauma Research. The Australasian Journal of Disaster and Trauma Studies, Volume 1997.

Wijkman, Anders and Timberlake, Lloyd, Prevention Better than Cure. Nottingham. UK: Earthscan Russel Press, 1984.

Yehuda, Rachel. Post-Traumatic Stress Disorder. The New England Journal of Medicine. Volume 346 (2002): 108-114. 